\title{
STARBUCKS MARKETING ANALYSIS
}

KATERINA HASKOVA

Starbucks first opened in Seattle in 1971 (Starbucks, 2014) and has grown from one store to 19,767 stores today. With over 160 thousand employees worldwide (Forbes, 2013) this company has become world famous and brings high quality coffee and beverages to its clients over the world daily. Their well-known mission statements is: to inspire and nurture the human spirit - one person, one cup and one neighborhood at a time.

In the Unites States of America 54\% of the population over 18 years of age drinks coffee daily and the total American drinking population spends 40 billion dollars on this beverage yearly (Harvard School of Public Health, 2014). According to the following statistics, there is large market potential in the world for this particular service and production; Starbucks along with many competitors, such as Costa Coffee or McCafe, have seized this opportunity and continue to innovate within this market. It is no doubt that this market can be profitable; in 2012 Howard Schultz, the CEO of Starbucks, was classified as the 8th best-paid CEO in the United States of America making 103 million dollars of profit (Rushe, 2013).

Throughout this report, we will be looking at the marketing techniques Starbucks uses daily and identify the key techniques that bring them the competitive advantage. Firstly, we will analyse the current marketing strategy, look into detail at their branding, and explain how it brings value to the customer, discuss the ethical engagements and importance of CSR used, and lastly, analyse the relationship between marketing strategies. 


\section{STARBUCKS' CURRENT MARKETING STRATEGY}

Every business needs to carry out a successful marketing strategy in order to be noticed by consumers and to forge brand identity. Throughout this section, Starbucks' marketing strategy will be described using the core marketing strategy concept, identifying the positioning and marketing mix, and analysing the environment in which it operates. Strategic marketing will further be used in complement with tools such as the Ansoff and BCG Matrix.

\section{CORE MARKETING STRATEGY}

A core marketing strategy analysis looks at segmentation, targeting, positioning, and differentiation. This type of analysis allows the company to understand the type of service they want to provide, which product type they are selling and to whom.

\section{SEGMENTATION}

At Starbucks, the demographic segmentation's main group is between 25 and 40 years of age with high incomes, the second target group is 18 to 24 year of age and belongs to richer families. In general, the customers belong to the Generation Y born between 1977 and 2000; this is where most profit is made as claimed by Fromm (2014). Psychographic segmentation indicates that customers belong to the upper-middle class and generally have college education (Rafii, 2013). When targeting, Starbucks is situated between mass marketing and segment marketing; they are targeting a broader public; however, there are some criteria that the customers should have, such as higher incomes or a younger age. We can illustrate Starbuck's positioning thanks to the graph (Zapolski, 2010) below; it is how the customers perceive the product and service sold.

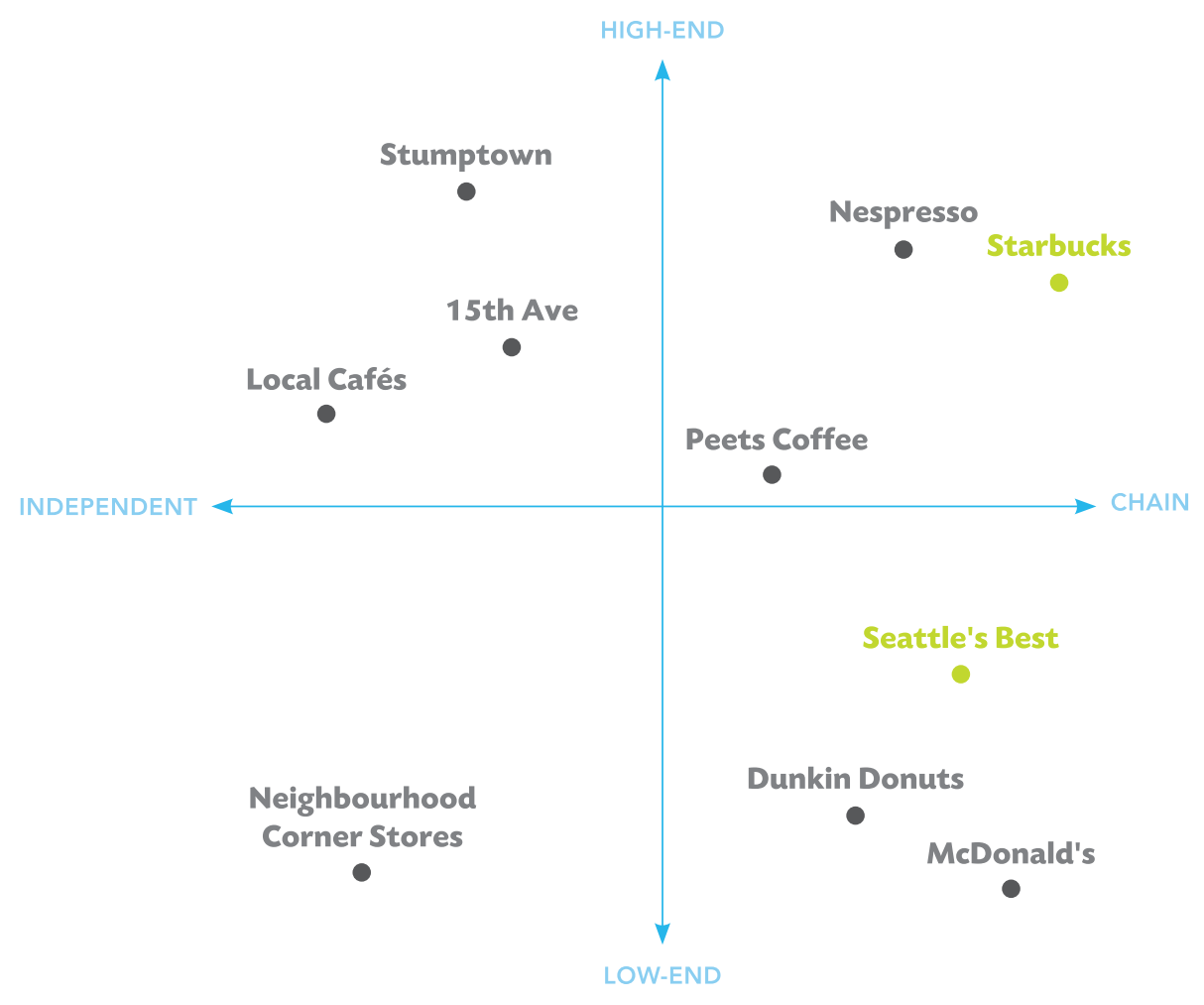

Figure 1: Starbuck's Positioning 


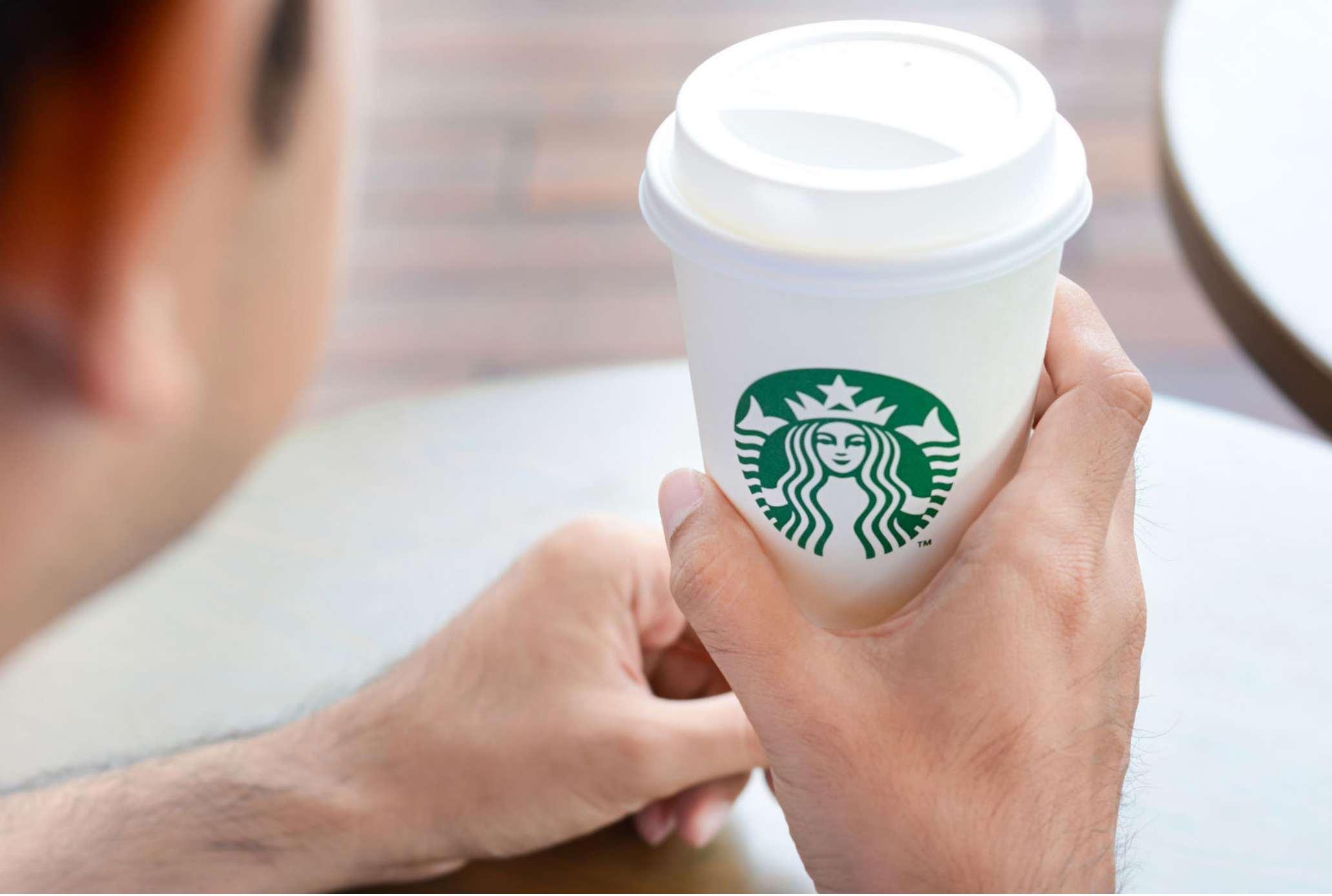

(C) kritchanut/123RF.COM

\section{STARBUCKS' POSITIONING}

As Blankson and Kalafatis (2007) point out in the Journal of Services marketing, positioning has received little attention from marketers but is very useful in defining and modifying the tangible characteristics of the product and its intangible perceptions. At Starbucks, customers are buying an expensive product of high quality (tangible), but they also have the personalised in-store experience enhanced by the trained employees, for example, the customer's name is written on the plastic cup their beverage will be served in (intangible); this helps Starbucks obtain the premium brand status and fight competition.

The unique selling proposition concept helps Starbucks differentiate their products and services and gain competitive advantage over competition. Starbucks is known for their good customer service and in-store experience, for customers can either spend some time in the shop and benefit from the friendly and cozy environment and $\mathrm{Wi}-\mathrm{Fi}$, or they can rapidly purchase their beverage and continue on their way. In both cases the customer is meant to take away a unique experience. This unique selling concept is especially important in a fast moving world where technology is becoming more personalised and where social interactions are decreasing; the customers can find some human contact in their everyday lives in a Starbucks store. Despite what Moore (2006) explains by claiming that Starbucks is by far the leader in the industry they have created; there are several criticisms facing Starbucks about their individual approach to customers. Sanburn (2012) explains that in 2010, when Starbucks opened several new stores, the company lost "some of its magic" and the individual service was not so personal anymore. Customers felt neglected and treated as a regular fast food customer, and this contradicts the unique selling proposition the company had laid out earlier during its creation and decreases the competitive advantage Starbucks detains over their competitors. 


\section{EXTENDED MARKETING MIX}

The extended marketing mix helps us understand the main activities undertaken by Starbucks as to best meet the needs of its targeted market. When it comes to product, three types are identified: served beverages and food, coffee for home, and mugs for sale (Starbucks, 2014). Beverages tend to bring the most profit; however mugs have become more of a culture to individuals around the world and helped Starbucks create their signature product worldwide. Packaged coffee that can be enjoyed at home was introduced last and is now available in stores. As Fernandez (2010) points out, customers find the coffee in large retail stores to be of lower quality, enjoy it less, and feel like Starbucks is only aiming for high profits instead of preserving the friendly environment.

Price is one of the main issues at Starbucks, a cappuccino costs around $£ 2.50$, a hot chocolate $£ 2.35$ (King, 2011). A mug costs between $£ 6$ and $£ 20$, and a pastry or other snack cost around $£ 3$ (Starbucks Store, 2014). Captive pricing is used, the baristas will always propose an extra product (e.g. reusable mugs) to make customers spend more. The highest volume of price criticism emerged from China where the media was very unsatisfied with the high prices of coffee (Kamenetz, 2013).

With 19,767 stores in 62 countries, Starbucks is famous for their ideal locations, and in Europe they are mostly present in large cities; however, in the United States we can find stores in small villages (Starbucks, 2013). With this many stores, promotion does not happen through television or radio, but rather through word of mouth, location in various parts of the city, and their online presence. Fidelity cards can be used to gain loyalty however the social and ethical image along with efficient public relations on social media are the main drivers of Starbucks' marketing. The ethical behaviour creates an image to which customers want to associate themselves with. Special language is used to order products in stores (Morriss, 2012) making the ordering process a brand on its own. As described by Ad Week (2013) the "All day. All summer." campaign (Starbucks Coffee, 2013) launched in 2013 helped to educate their customers to drink coffee several times per day in different forms (lattes, slushies, milkshakes...) which enhances promotions and increases Starbucks' sales by creating a virtual need.

The staff at Starbucks is highly trained and taught to deal with problems quickly following company's models (Bdaily, 2013). Motivation at Starbucks is high since social responsibility is also applied to its employees who can develop careers and have adjusted working times (Nelson, 1998). As Wood (2011) indicates in The Guardian, every employee is entitled up to $£ 500$ of shares depending on their job position. Motivation is very high and the employees work in a community, and this helps to have a friendlier and relaxed environment to work in, benefiting both the employees and the customers.

The process of product manufacturing at Starbuck's is transparent and publicly accessible, for individuals are aware of the origins of their coffee or tea thanks to reports done by fair-trade organisations. Physical evidence is further given through the eco-friendly design of interiors to which individuals wish to be associated.

\section{MARKETING ENVIRONMENT ANALYSIS}

It is crucial to be aware and understand the environment in which a company is operating in order to implement their strategies successfully. The Micro environment can be analysed using a SWOT analysis and further completed with a Macro environment study by doing a PEST analysis.

A table of Starbucks SWOT analysis can be found in Appendix 1, as explained by The Economist (2009), this analysis is very subjective and can only provide a certain background to Starbucks. In this case, the environment analysis must focus on the external factors since internal factors are rather analysed in the core marketing strategy and extended marketing mix. 
The Macro environment refers to everything external to the organisation, in other words, factors Starbucks cannot necessarily fully control, only influence. According to Turner (2011), PEST analysis stands for political, economic, social, and technological and helps us analyse this particular environment. For the following analysis, we will base the company in the United Kingdom where Starbucks' main competitors are Costa Coffee, Pret a Manger, and Caffee Nero (Hale, 2013).

Certain political issues can arise since coffee beans are grown in developing countries, and this could raise questions about the working conditions and child labor. Tariffs and import taxes could also influence the prices in stores considerably not forgetting that economic factors such as the economic recession or exchange rates could threaten Starbucks' profits.

According to the UK Tea $e$ Infusions Association (2014), the largest per capita tea drinking nation is Britain where 165 million cups of tea are drunk daily versus 70 million cups of coffee. While younger generations may be moving towards new American trends such as having coffee or frappes at any time of the day, Starbucks must adjust their product portfolio and propose more tea. The ethical social factor and desire to be eco-friendly is also evolving, Starbucks must adjust to this trend.

Finally, the development of new technologies and user friendly machines, such as home coffee machines, quality of beverages in other restaurants served are increasing and Starbucks should create the Starbucks experience at home by manufacturing their own capsules machine with their coffee and tea. The emergence of social media is already used by Starbucks especially via Twitter where gift cards can be purchased and sent to friends (Starbucks, 2014).

\section{STRATEGIC MARKETING}

Starbucks could introduce a strategic business unit specialised in tea, as mentioned above; tea sales represent a large potential in countries like Britain or Ireland. As Tietjen (2013) mentions, coffee sales at Starbucks are already acquired and the company must now focus on the tea market. Translating this information into a BCG Matrix, coffee at Starbucks is already a "Cash Cow" which brings profit without any further investment or effort needed. The introduction of tea would fall under the "Question mark" category, a low market share but a high business growth rate. If the introduction of more tea products would become successful in the UK, the product could even shift to a "Star" category to later join the "Cash Cow" as illustrated below.

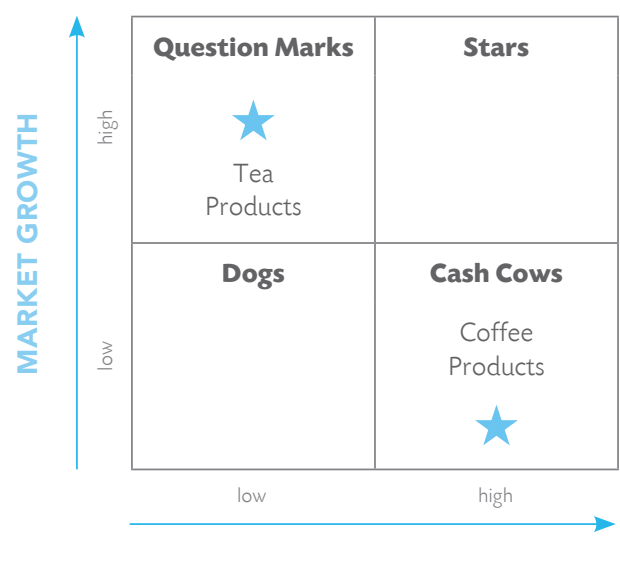

RELATIVE MARKET SHARE

Figure 2: BCG Matrix applied to Starbucks' products 
While the Boston Consulting Group Matrix allows us to have an idea of where products or services stand, it has faced several criticisms such as the fact that one cannot always be sure whether an industry is mature or not and misjudge the product placement. It has also been said that this matrix persuades companies to excessively focus on market share and missed opportunities (The Economist, 2009) and therefore Starbucks must use it in combination with the Ansoff Matrix.

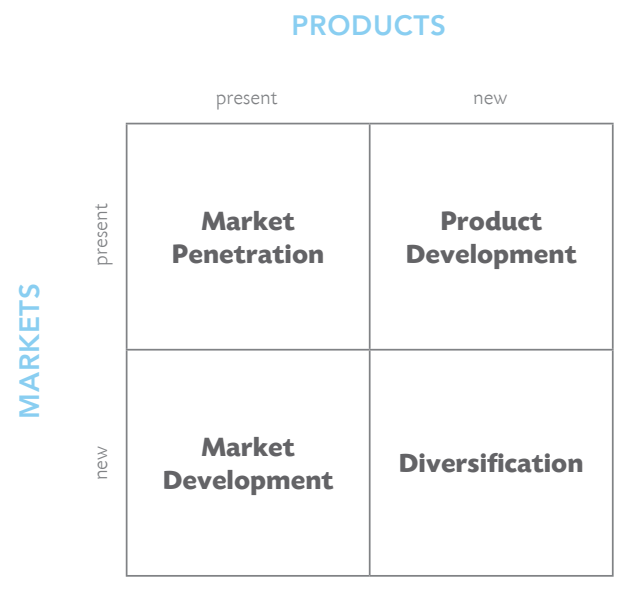

Figure 3: Ansoff Matrix.

According to The Guardian (2014), Starbucks is aiming to increase their evening sales since coffee before bed is unpopular by introducing the sales of alcohol beverages such as wine or beer. Following the Ansoff Matrix shown above, this strategic move could be qualified as product development or even diversification since it would be leaving the coffee market and becoming an evening bar industry.

In conclusion, Starbucks does have various marketing strategies which generally rely on customer loyalty and word of mouth or the ethical considerations of the company along with involvement in the community. Thanks to the extended marketing mix and core marketing strategy analysis, internal factors can be analysed and the PEST analysis gives an overview of the external environment. While Starbucks is still perceived as a luxurious and responsible brand, there are several issues arising and putting their competitive advantage in danger: the perception of tax evasion or mass-production is hurting the brand's image and dissuading customers to purchase their products. In the future, Starbucks must return to their core marketing strategy and focus on their customer's individual needs and wants.

\section{IMPORTANCE OF STARBUCKS' BRAND AND HOW ITS VALUE FOR THE CUSTOMER}

According to Kotler, brand management is about "creating, communicating and delivering value to a target market at a profit (CCDVTP steps)" (fado86, 2009). In order to achieve the CCDVTP steps there are three types of management practices that must be fulfilled: product management for value creation, customer management for delivering the value, and branding management for the communication of these values. Throughout this question three main parts will be discussed; the importance of product management that is developed with a Product Life Cycle analysis and attributed copyrights, Starbucks' brand equity development, and lastly, how Starbucks delivers value through customer management and community developments. 


\section{PRODUCT MANAGEMENT AND PRODUCT LIFE CYCLE}

By using the Product Life Cycle curve, product management understands which products they are selling and are therefore able to determine their value. It is the product management's job to transmit these product traits to the customer in order to create value. At Starbucks the core product is a hot or cold beverage, the tangible product is tea or coffee, the augmented product is the tangible good in combination with the personalised friendly service and the potential product could be the evolution of the product portfolio towards other beverages such as alcoholic drinks. Represented on the PLC graph, Starbucks' products would look as follows:

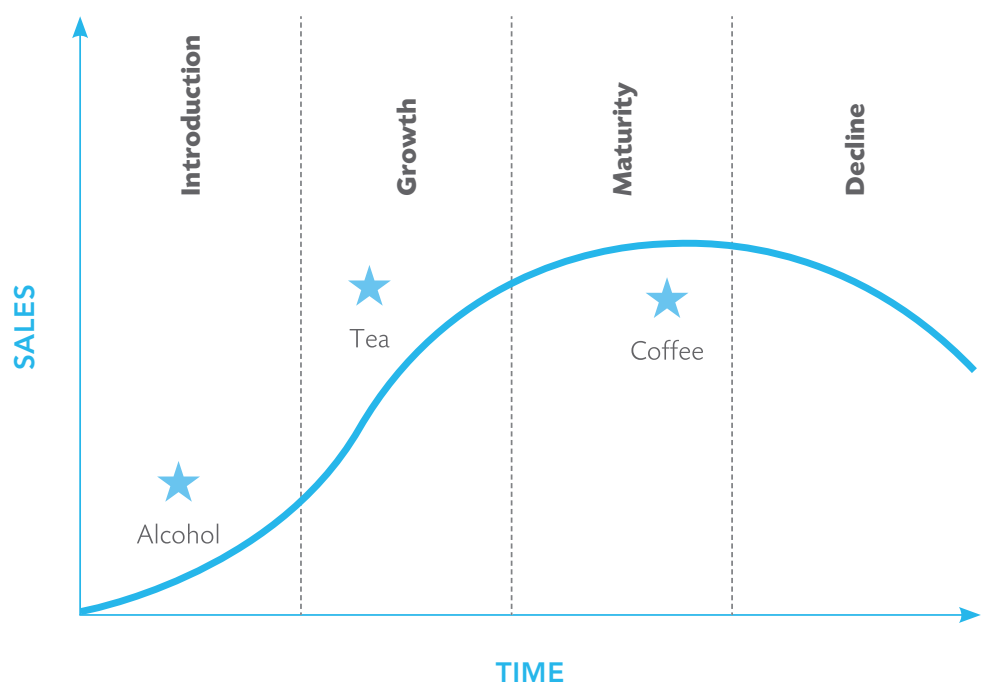

Figure 4: Product life cycle of Starbucks tea er coffee

While coffee sales are acquired and are at a maturity stage (could be considered as tuxedos products), Starbucks must still make an effort on the brand management for tea and discover a way to develop the evening alcohol sales. Starbucks product management can further determine two product categories: durable (mugs and souvenir objects) and non-durable (beverages sold). Trademarks play an important role in the protection of the "Starbucks culture", due to the copyrights and registered trademarks all the beverage names, images, logos, slogans, or websites common to the company cannot be copied by anyone else (Starbucks, 2014). This protects the environment and culture the company has and allows them to maintain their competitive advantage.

The products are the starting point to creating value for customers; if they are high quality products that are differentiated from other companies, the customer will remember this and forge his or her idea of the brand. Once these product attributes are determined, brand equity comes into place to communicate and confirm the company's values.

\section{BRAND EQUITY}

As explained by Lindemann (2010), Tong and Hawley (2009), or Kapferer (2005), brand equity is customerbased and financial-based; at Starbucks the branding has been crucial for their success since it has added financial value (more expensive services and products) and customer value (respect towards the brand, loyal customers). There could however be a reverse effect of brand equity after the criticisms of Chinese media claiming Starbucks' products are too expensive (Kamenetz, 2013) or underlining that the company is not paying tax (Bergin, 2012). Customers could attribute a negative image to Starbucks degrading the value it represents as a company. 
Guzman (2012) argues that a brand with positive equity is considered to have high strategic value and stronger consumer preferences; however, by not respecting one's own values, this could damage the consumer's preference and contribute to a loss of competitive advantage. Brand equity is strongly correlated with customer management; quite often it is observed that companies with strong brand equity have a community of fans willing to support them and their products.

Kotler and Keller (2006) believe that for companies like Starbucks branding is essential for their success as it generates customer loyalty which provides companies with security, predictability of demand, and creates barriers against competition. In their research, Sisodia, Sheth, and Wolfe (2007) identify the most valued organisations worldwide by international consumers. Starbucks was one of the 25 companies along with IKEA, Harley Davidson, Toyota, and Whole Foods that were most voted for; a large percentage of consumers could not imagine living without this brand. The authors further found that the following companies had very high employee satisfactory levels which created a friendly and relaxed working atmosphere. Starbucks decided to create value for its customers through this matter; the friendly in-store experience differed from other fast food stores and helped them gain competitive advantage.

Unfortunately, six years later, Shaughnessy (2013) from Forbes announced that Starbucks is losing its reputation while large fast food businesses such as $M c D o n a l d s$ are gaining popularity. The reason behind this is a breach of customer trust, the value that had been created by the Starbucks brand had been violated by tax evasion in the UK or degrading of individual service.

Kotler believes that customer satisfaction comes from the experience the customer has from purchasing or consuming the product/service (Fatmir Hyseni, 2013). After Starbucks' market expansion during the 21st century, customers felt that the individual approach of service was neglected and that Starbucks' main slogan and competitive advantage was lost. While Starbucks' differentiation technique was high quality coffee and excellent service, customers started shifting towards McDonalds or Costa coffee where they got similar services for a cheaper price.

Since the individual customer service approach is more and more difficult with an increasing demand and lesds time to serve the individual, Starbucks decided to create brand value through the development of communities. Mainly centered on corporate social responsibility, the company attempts to unite its customers under two main causes: protect the environment and encourage fair-trade. Being a manufacturer brand, Starbucks promotes the ethical side to selling farmer quality coffee and this gives the company a certain image. Nowadays, customers generally want to be associated to this type of ethical behaviour, and so as Kasolowsky (2014) explains, customers are willing to pay more for extra service even though they could find the same quality for cheaper elsewhere. This sense of belonging is part of Maslow's (1943) hierarchy of needs, when an individual feels part of a community he or she is happier.

Such behaviour and customer loyalty is important for the future, as Grissafe (2014) explains in the American Marketing Association journal, individuals create a relationship with brands and word of mouth is very important as it establishes trust. If a mother drinks Starbucks, her child will have a tendency to want to drink the same product as her. Winchester et al. (2008) further explain that there is a relationship between associating a brand with a belief and consumer brand choice, and it is therefore very important for Starbucks to communicate a positive image of their brand in order to attract customers and create value for them. 


\section{STARBUCKS LOGO}

The use of the logo at Starbucks is crucial since it can be found on every product and is nearly recognised by all individuals worldwide; created in 1971 it has evolved during the years. As Brassington and Pettitt (2006) explain, the logo and brand name must be distinctive, supportive, acceptable, and available. Despite the fact that Starbucks is a freestanding brand name (the name does not describe the product) customers still link it directly to the products and services provided. The logo has been simplified over the years in order to be more easily recognizable. As Dooley (2012) discovered, the less detail you utilize, the more likely the customer will remember it. The evolution can be noticed below:

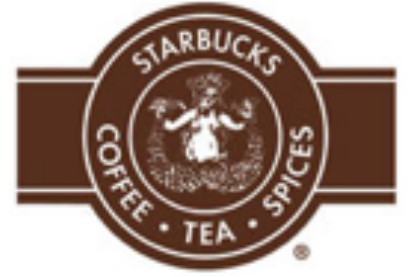

1971

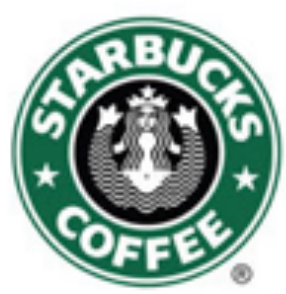

1987

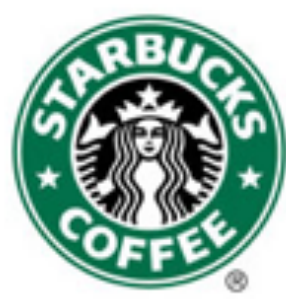

1992

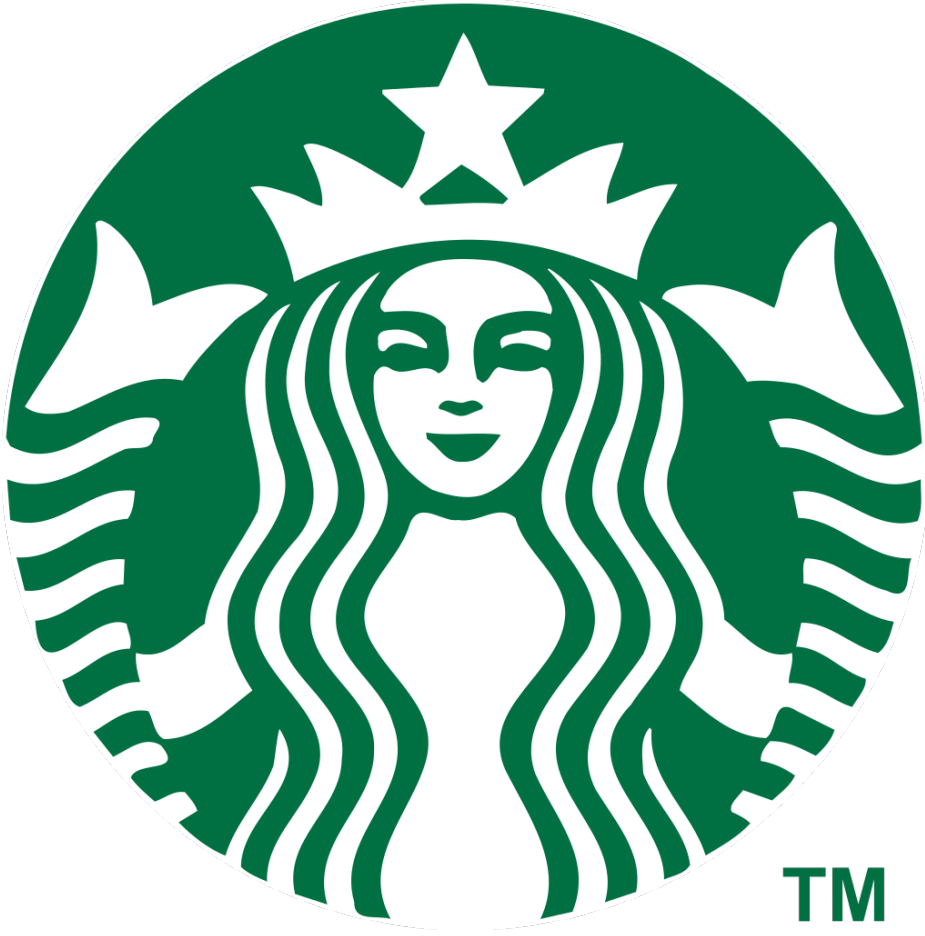

2011

Figure 5: Starbucks logo evolution from 1971 to 2014

Starbucks was highly criticised in 2011 for removing the company name from their logo in order to launch other products; customers associated coffee so strongly with the company name that these measures had to be taken. As Hollis (2011) explains, customers do not like change and will feel betrayed for losing the logo they are emotionally attached to, and this could negatively affect Starbucks's sales. Overall brand management is very important since it is the appearance of the company, the cover by which the consumers will judge the book. Starbucks has put down a set of values for the customers that help them gain competitive advantage; however, it is crucial to respect these values in order to maintain customer trust and high profits. Since fair-trade is practiced, Starbucks can afford to put in place premium pricing without the customers complaining; when they are buying a coffee they are also donating to the local farmers in developing countries and take away a sense of responsibility. This makes them part of the Starbucks culture and community and helps Starbucks differentiate from their competitors. 


\section{ETHICAL ANALYSIS \& THE IMPORTANCE OF CORPORATE SOCIAL RESPONSIBILITY}

Various companies present in today's market operate with a given set of ethical values with particular attention to corporate social responsibility. In an evolving world where social media is gaining importance, it is more and more crucial to defend ethical values and have rules in place. As explained by Podnar and Golob (2007) in the Corporate Communications: An International Journal, taking a CSR marketing orientation is a value creation that goes beyond profit maximisation, but includes the long-term business survival by meeting the stakeholder's societal expectations.

According to Brassington and Pettitt (2006), there are various marketing philosophies a company can follow such as production, selling, marketing or societal-marketing philosophies. Starbucks follows the societal-marketing philosophy based on the marketing concept; they attempt to add a societal benefit to their brand by helping communities or respecting the environment.

In 2011 Porter and Kramer introduced the concept of CSV - Creating Shared Value - best explained as "policies and operating practices that enhance the competitiveness of a company while simultaneously advancing the economic and social conditions in the communities in which it operates". While in the past most organisations focused on following CSR policies, the tendency is now moving more towards CSV; according to Porter and Kramer (2011), the companies that have embedded it the most in their operations are Nestle, Unilever, or Johnson e Johnson.

Put simply, companies aim to make high profits and CSR can stimulate employee's happiness or facilitate employee retention which is positive for Starbucks or any other business. As Bhattacharya et al. (2008) illustrate, according to the surveys made in large American companies, 90\% of the employees believe it is important for the company to be engaged in CSR. Bhattacharya et al. (2008) further explain that there is an increase in tendency for employees that prefer working for companies with corporate social responsibility since it contributes to the "employee value proposition". While money can keep a person in the company physically, CSR can keep them there emotionally. Meister (2012) shows that 35\% of employed Americans would take a $15 \%$ pay cut to work for a company committed to CSR and $58 \%$ to work for an organisation with values like their own.

In the Starbucks Global Responsibility Report (2013) employees are addressed as "partners" giving them a sense of belonging to a community where the relationship with management is more open than a classic employee position. Starbucks invests in youth leadership; thousands of $15-24$ year-olds are trained and educated through Starbucks educative programmes yearly and later become store managers or assistants. This is where Starbucks executes their CSV practices, and while this demands a budget, it is profitable for both parties in the long-term, where young individuals receive free education and a potential career while Starbucks gains a positive image in the community and invests into training from the earliest age.

CSV benefits employees and contributes to motivation but also supports branding. According to the chief ethics and compliance officer of Starbucks, Matthew Swaya, ethical behaviour from the company and their partners has a fundamental impact on the brand; it informs the customers how the company behaves and gives them a sense of responsibility (Marzec, 2014). He also believes that it is meaningful to their customers that they support a company with such strong ethical values. The Dove brand launched their "campaign for real beauty" which told women they are beautiful in every way and tried to show the unethical behaviour done by other brands in commercials (using Photoshop to create unrealistic "perfect" people). This ethical campaign worked and increased sales by $20 \%$ (Joni, 2011); customer satisfaction and involvement is therefore crucial for profit maximisation. 
The emergence of social media where communication through this channel is immediate, permanent, and extremely public creates an opportunity for companies to communicate ethical values to their consumers but can also be a threat in case unethical behaviour is identified. As underlined by Kramer (2006), the media have become adept of underlining the social consequences of company's activities and so there is no place for unethical behaviour.

According to Social Bakers (2014), Starbucks is the 5th most "liked" page on Facebook with 36,188,108 fans worldwide and the second most "followed" brand worldwide on Twitter right after Samsung Mobile. Coca-Cola is using this communication channel to show that they are transparent, and they protect and respect customers, as well as are responsible and monitor correct behaviour (Coca Cola, 2014) and Unilever has done their branding through ethical advertisements and a high presence on social media (Boynton, 2013). As Krauss (2014) shows, more and more companies such as Nike or Subway are developing CSR via social media by involving customers (e.g. if they click "like" on facebook, one tree will be planted).

Overall, in 2014 Starbucks was part of the 114 "2014 World's Most Ethical Companies" ranking in reward for their ethical coffee sourcing, local farmers support programme, and the eco-friendly stores and materials used. By 2015, Starbucks wants 100\% of their coffee to be ethically sourced (95\% in 2013) and wants to expand their ethical values to their competitors in order to make a world-wide impact on increasing farmer's rights and standard of living. The stores are being built with recycled materials, and the cups in which beverages are served are also 100\% recyclable (Starbucks, 2013). Clearly, the friendly environment in combination with building strong ethical values has increased Starbucks sales; just by looking at the share values, in 2010 a share in Starbucks was worth $\$ 23.28$ and now $\$ 76.95$ at the beginning of 2014. The numbers have almost multiplied by four in only four years.

\section{Engaging in CSR and CSV is inevitable for businesses in today's market; however, a bad execution of these values can also cost them loss of profits and customers.}

In the case of Starbucks who presents itself as a highly ethical company, we cannot ignore the tax evasion issues that are happening in the UK. As described by Bergin (2012), Starbucks avoids UK tax yearly by reporting zero profit and so paying zero income tax while claiming that the business in UK is doing great and that it should be an example to different countries. This gave rise to negative public reactions as shown by Bergin (2014) or Sky News (2014), and Starbucks sales dropped by 3.4\% in one year. Several boycotts and public criticisms emerged and the brand lost its ethical value image.

HerM had several issues when in 2012 TV4 claimed that HerM's workers are paid less than $\$ 0.45$ an hour and work in terrible conditions (The Local, 2012). Customers over the world participated in boycotts and tried to degrade the company's brand. Nike had bigger problems in the 90 s when various scandals linked to working conditions were raised. As Nisen (2013) underlines, the conditions in Bangladesh caused many boycotts and damaged the company's image and sales, and as Yahoo Finance (2014) shows, in the 90s Nike's sales were very low, and there was a particular drop in share value at the end of 1993. The same happened for France Telecom, as Todd (2012) shows, 35 suicides took place between 2008 and 2009 due to psychological harassment. Not only was the public's reaction negative and the brand image was hurt, but Google Finance (2014) shows a considerable drop in share value between 2008 and 2009. 
We can say that CSR and the respect of ethical values leads to a company's success if it is done in the right way, and there is a general increasing trend that customers associate the brand with the company's actions and remember every negative aspect communicated by the media. It is therefore almost impossible in today's market not to have ethical values and neglect CSR. While some companies such as Starbucks have very strong CSV plans and participate in improving life in communities, they can also be doing very unethical practices that will always dominate over the good being done. For some companies, the use of CSR and CSV seems to be an excuse to do unethical actions in other sectors, and even though a desire to make the world a better place is there, companies generally need CSR and CSV to maximise their profits.

\section{STARBUCKS' RELATIONSHIP MARKETING STRATEGIES}

"To succeed or simply to survive, companies need a new philosophy. To win in today's marketplace, companies must be customer-centered - they must deliver superior value to their target customers" (Kotler et al., 2008).

As Kotler et al. (2008) describe, customers are influenced by advertisement and their entourage. Setting realistic expectations is important in marketing; if the service is better than expected, the customer will be positively surprised and therefore happier. Starbucks has a set of values that have remained unchanged since their opening in 1971. Their mission statement "one person, one cup and one neighborhood at a time" sets very high customer expectations and promises a unique experience; customers expect to be given high attention and great customer service. As explained by Veloutsou et al. (2002) maintaining this type of relationship with the client helps the company gain competitive advantage. The quality of coffee is also stressed all around the world.

According to Mullaney (2014), the reality is different, with 16,000 stores worldwide Starbucks no longer provides the individual customer service it used to and is perceived more as a fast food coffee chain rather than a café where businessmen used to have their meetings. Staff (2014) explains that seven individuals over the world are in charge of the quality control of 400 million pounds of coffee yearly making it impossible to control every single coffee grain as Starbucks promises to.

Despite these issues, Starbucks continues to promote a highly friendly and interactive relationship with its customers; by launching the MyStarbucksidea.com website (2013) they show that the level of relationship formed with the customer is at the partnership level. On this website customers can provide continuous feedback on products or suggest new products or services. Some of the suggestions are taken into consideration by Starbucks, and the customers can follow its development online. There are benefits for both the customers and Starbucks in conducting this service, for while customers obtain the products they want and have better service based on their demands, Starbucks does not have to invest into research and development or satisfactory surveys that are too costly or time consuming. This however, only works for individuals that have been to Starbucks, and in order to determine how to attract new clients and calculate the budget for advertising, we can use the customer lifetime value method. 


\section{CUSTOMER LIFETIME VALUE METHOD}

The customer lifetime value method (further LTV) is the projected revenue that a customer will generate during their lifetime (Kissmetrics, 2014). According to the Starbucks case study, if we calculate the average spending of a Starbucks customer multiplied by the number of visits per week, we obtain that this customer will bring Starbucks a $\$ 14,099$ profit in their lifetime. Respecting this prediction, Starbucks should not spend more than this amount in advertising and customer retention techniques, and this budget limit allows them to maintain high profits without excessively spending on advertising. Having a set budget, Starbucks can send promotional messages to their customer and offer them reduction coupons on their favourite products; benefits are mutual, customers purchase at lower prices and Starbucks has a constant cash flow in their stores.

Customer loyalty was highly discussed in the 70s with theories by Jacoby (1971) or Jacoby and Chestnut (1978) when the distinction between behavioural loyalty and cognitive loyalty was made. In general, the authors agreed that customer loyalty is the act of a non-random repurchase (behavioural loyalty), after following a process of evaluation (cognitive loyalty). At Starbucks, behavioural loyalty is created through the quality of products and good customer service; however, if customer service begins to decrease, there will be a variation in budget necessary to maintain this behavioural loyalty.

On the other hand, cognitive loyalty is more difficult to embrace, and Starbucks generally strengthens it with the loyalty cards that customers use to accumulate points which they later exchange for free beverages or goods found in the e-shop. One can also become a gold member and have higher benefits. As Rust et al. (2010) explains that the loyalty card brings more benefits to the company than to the customer; it helps Starbucks track what products the customer is buying and which stores he or she visits. This information is later used for product proposition: customers will get special custom offers with their favourite products and give them the feeling they are saving money by buying bigger quantities at lower price.

Starbucks has been criticised for the way they handle their customers, as Dooley (2013) shows a golden customer must earn 30 stars per year, and if this is not met, the number of points are set back to zero and the customer goes back to a green level card (basic). Many customers rebelled against this policy claiming they were not warned of this action and switched to competitors. Crookes (2012) shows customers must spend more today compared to 2011 to gain the same rewards. For managing these activities more efficiently, Starbucks needs to have a solid CRM in place.

\section{CUSTOMER RELATIONSHIP MANAGEMENT}

Customer Relationship Management, as defined by Rigby and Ledingham (2004), is put in place to track and strengthen customer relationships. At Starbucks the membership card plays a role in tracking the number of sales per customer and helps determine whether it is worth investing in keeping this customer or not. Murphy (2011) explains that Starbucks' store managers are equipped with personal laptops that help them share their experience with other store managers via the company cloud, and they can exchange opinions to improve customer satisfaction. One of the most successful CRM launches was the Starbucks mobile app through which customers could pay at Starbucks - within a year Starbucks handled 20 million transactions in total.

Social media is also part of Starbucks' CRM, for they have a very strong presence on websites such as Twitter and Facebook where they interact and maintain a relationship with their customers. Despite this effort, customers complain that Starbucks takes too long to answer their questions and generally replies off topic (Branding Personality, 2014). 
Social media combined with the loyalty card facilitates observing the churn rate, Starbucks must pay attention to this indicator since it shows how many loyal customers are lost and are alerted, thanks to special software, when the customer is starting to lose interest for the brand (e.g. less sales and store visits). As Traynor (2014) underlines, churn rate must be one of the most monitored pieces of information so that the company has time to react to a declining loyal customer in order to bring him back and minimise the costs to do so. According to Fournier et al. (1998), a company must not "overkill" its customer with information and mail them every day since this leads to customer dissatisfaction and loss of customer loyalty, and so this is not a solution Starbucks should be using to regain their customers.

There is no real benefit for the customer in CRM practices since they are built to make them spend their money; however, they could be the practice that gives the customer the feeling of being special since the company is "fighting" for him or her. The benefit lies in the hands of Starbucks, who through the use of these techniques, retains the maximum loyal customers possible and maximises their profit.

In general, we can say that relationship marketing is crucial for companies today since businesses have a more "human" image opposed to mass-marketing from the 1920s. Starbucks is handling relationship marketing in an efficient way by creating an interactive environment similar to social media and by supporting the community spirit. Customers appreciate sharing their ideas for improvement on their website "My Starbucks Idea" and therefore feel more loyal towards the brand.

\section{CONCLUSION}

Starbucks is a great example of a company that has built their marketing strategy around their customers and ethical behaviour instead of investing millions of dollars on advertising that does not bring any social benefit. The advantage of this company is the market they are operating in; there is always a demand for coffee, and people regularly visit cafés before work or to spend time with their close ones. The challenge is to retain these customers and give them an envy to come back.

With a target population between 18 and 40 years of age, there is opportunity for different strategies; the store proposes high quality coffee for difficult consumers and fresh, creative beverages for the younger age while conserving the premium brand image. Starbucks does not only sell beverages, but also a social image because most consumers want to be associated with this brand which is perceived as a high quality upper-middle class location.

Execution of corporate social responsibility is one of Starbucks' main strategies; participating in the improvement of coffee and tea farmer's lives is their priority together with saving the environment through more eco-friendly stores, reducing water consumption or serving coffee in recyclable cups. Further, their implication on social media to be close to their customers is also part of their marketing strategy by getting individuals involved in projects and ideas for future improvement are welcome and in the end, the research and development is done for free by their customers.

While Starbucks can be criticised for expanding too rapidly and harming local cultures by transforming them into an American experience, it is loved my most consumers and highly followed on social media. In the future, Starbucks should continue expanding their product portfolio and closely follow new technological trends as their target population has this expectation. With an increasing number of customers, Starbucks must be well organised and pursue their individual client approach which makes their brand so unique and makes the customers come back regularly. Overall, however, Starbucks is very successful in doing this and has constantly increasing profits yearly. 


\section{REFERENCES}

Ad Week (2013) '10 Brands Than Changed the World' [Video], Ad Week, 20 November [Online]. Available at: http:// www.adweek.com/video/advertising-branding/10-brands-changed-world-video-153983 (Accessed: 3 May 2014).

Bdaily (2013) 'Starbucks: 3 Inspirational Ways it Develops its Staff', Business Daily, 12 June [Online]. Available at: https:/ / bdaily.co.uk/opinion/12-06-2013/starbucks-3-inspirational-ways-it-develops-its-staff/ (Accessed: 3 May 2014).

Bergin, T. (2012) 'Special Report: How Starbucks avoids UK taxes', Reuters, 15 October [Online]. Available at http:// uk.reuters.com/article/2012/10/15/us-britain-starbucks-tax-idUSBRE89E0EX20121015 (Accessed: 11 May 2014).

Bergin, T. (2014) 'Starbucks suffers first UK sales frop after tax criticism', Reuters, 24 April [Online]. Available at: http:/ / uk.reuters.com/article/2014/04/24/uk-starbuckstaxbritain-idUKBREA3N0X020140424 (Accessed: 11 May 2014).

Bhattacharya, C.B., Sen, S., Korschun, D. (2008) 'Using Corporate Social Responsibility to Win the War for Talent', MIT SLOAN Management Review, 49(2), pp. 37-44.

Blnakson, C. and Kalafatis, S.P. (2007) 'Positioning strategies of international and multicultural-oriented service brands', Journal of Services Marketing, 21(6). pp. 435-450.

Boynton, J. (2013) 'How the Voice of the People Is Driving Corporate Social Responsibility', Harvard Business Review, 17 July [Online]. Available at: http://blogs.hbr.org/2013/07/how-the-voice-of-the-people-is/ (Accessed: 3 May 2014).

Branding Personality (2014) How Starbucks Built and Engaging Brand on Social Media [Online]. Available at: http:// www.brandingpersonality.com/how-starbucks-built-an-engagin-brand-on-social-media/ (Accessed: 13 May 2014).

Brassington, F. and Pettitt, S. (2006) Principles of Marketing. 6th end. Essex: Pearson Education.

Coca-Cola (2014) Social Media Principles. Available at: http://www.coca-colacompany.com/stories/online-socialmedia-principles (Accessed: 3 May 2014).

Crookes, D. (2012) 'Starbucks customers react angrily to loyalty scheme changes', The Independent, 13 May [Online]. Available at: http://www.independent.co.uk/life-style/gadgets-and-tech/news/starbucks-customers-react-angrily-toloyalty-scheme-changes-6288008.html (Accessed: 13 May 2014).

Dooley, R. (2012) Brainfluence: 100 Ways to Persuade and Convince Consumers with Neuromarketing. Hoboken: John Wiley er Sons, Inc. Dooley, R. (2013) 'Starbucks: Loyalty Program Misfire', Forbes, 23 July [Online]. Available at: http://www.forbes.com/ sites/rogerdooley/2013/07/23/starbucks-gold/ (Accessed: 13 May 2014).

Fado86 (2009) Kotler 2008 brand management. Available at: http://www.youtube.com/watch?v=xVAi81SKRKA (Accessed: 3 May 2014).

Fatmir Hyseni (2013) Philip Kotler on creating a cult brand. Available at: http://www.youtube.com/watch?v=C-Mlre11sxc (Accessed: 3 May 2014).

Fernandez, J. (2010) 'Starbucks takes ready brew coffee into supermarkets', Marketing Week, 6 July [Online]. Available at: http://www.marketingweek.co.uk/starbucks-takes-ready-brew-coffee-into-supermarkets/3015441.article (Accessed: 12 May 2014).

Forbes (2014) 'World's Most Valuable Brands', Forbes, May [Online]. Available at: http://www.forbes.com/ companies/starbucks/ (Accessed: 3 May 2014).

Fournier, S., Dobscha, S., and Mick, D.G. (1998) 'Preventing the Premature Death of Relationship Marketing', Harvard Business Review, January [Online]. Available at: http://hbr.org/1998/01/preventing-the-premature-death-ofrelationship-marketing/ar/1 (Accessed: 3 May 2014).

Fromm, J. (2014) Why Starbucks is Still Number One With Millennials. Available at: http://millennialmarketing.com/ 2014/02/why-starbucks-is-still-number-one-with-millennials/ (Accessed: 3 May 2014).

Google Finance (2014) Orange SA [Online]. Available at: http://www.google.com/finance?q=EPA:ORA (Accessed: 11 May 2014).

Great Place to Work (2013) FORTUNE's 100 Best Companies to Work For $®$. Available at: http:/ /www.greatplacetowork. net/best-companies/north-america/united-states/fortunes-100-best-companies-to-work-forr/1556-2013 (Accessed: 3 May 2014).

Grisaffe, D. (2014) 'Feeling the Brand Love', American Marketing Association, [Online]. Available at: https://www.ama.org/publications/MarketingNews/Pages/Feeling-the-Brand-Love.aspx (Accessed: 1 May 2014). 
Guzman, F. and Iglesias, O. (2012) Challenges facing brand managers today. Bradford: Emerald Insight.

Hale, S. (2013) 'Coffee countdown: Which is the best high-street student coffee shop?', The Independent, 9 October [Online]. Available at: http://www.independent.co.uk/student/student-life/coffee-countdown-which-is-the-besthighstreet-student-coffee-shop-8867073.html (Accessed: 3 May 2014).

Hollis, N. (2011) 'Starbucks' New Logo: A Risky Move', Harvard Business Review, 7 January [Online]. Available at: http:// blogs.hbr.org/2011/01/starbucks-new-logo-apple-or-le/ (Accessed: 13 May 2014).

HerM (2013) HerM Conscious Actions - Sustainability Report 2013 [Online]. Available at: http://sustainability.hm.com/ content/dam/hm/about/documents/en/CSR/reports/Conscious\%20Actions\%20Sustainability\%20Report\%20 2013_en.pdf (Accessed: 3 May 2014).

HSPH (2014) 'Coffee by the Numbers', Harvard School of Public Health [Online]. Available at: http:/ www.hsph.harvard. edu/news/multimedia-article/facts/ (Accessed: 3 May 2014).

Jacoby J. (1971) 'Brand Loyalty: A Conceptual Definition', American Psychological Association Proceedings, 6, pp. 655-656.

Jacoby J. and Chestnut R.W. (1978) Brand Loyalty. Measurement and Management. New York: Wiley.

Joni, S. (2011) 'Beware the Hidden Traps in Cause Marketing', Forbes, 20 October [Online]. Available at: http://www. forbes.com/sites/forbesleadershipforum/2011/10/20/beware-the-hidden-traps-in-cause-marketing/ (Accessed: 3 May 2014).

Kamenetz, A. (2013) 'Starbucks is too damn expensive, says Chinese media', Fast Company, 21 October [Online]. Available at: http://www.fastcompany.com/3020281/fast-feed/starbucks-is-too-damn-expensive-says-chinese-media (Accessed: 12 May 2014).

Kapferer, J.N. (2005) The New Strategic Brand Management. Creating and Sustaining Brand Equity Long Term. London: Kogan Page. Kasolowsky, N. (2014) 'Maintaining Customer loyalty', American Marketing Association, January/February [Online]. Available at: https://www.ama.org/publications/MarketingInsights/Pages/Maintaining-Customer-Loyalty.aspx (Accessed: 3 May 2014).

King, M. (2011) 'Store Wars: Caffe Nero and Starbucks', The Guardian, 23 September [Online]. Available at: http:/ / www.theguardian.com/money/blog/poll/2011/sep/23/store-wars-caffe-nero-starbucks (Accessed: 3 May 2014).

Kissmetrics (2014) Lifetime Value. Available at: http://blog.kissmetrics.com/how-to-calculate-lifetime-value/?wide=1 (Accessed: 3 May 2014).

Kotler, P., Armstrong, G., Wong, V. and Saunders, J. (2008) Principles of Marketing. 5th edn. Essex: Pearson Education Ltd. Kotler, P. and Keller, K.L. (2006) Marketing Management. Upper Saddle River, NJ: Pearson Education.

Krauss, M. (2014) 'Authenticity: One Ad Man's View', American Marketing Association. [Online]. Available at: https://www.ama.org/publications/MarketingNews/Pages/michael-krauss-twitter-facebook-linkedin-social-mediabarry-krause-livelab.aspx (Accessed: 1 May 2014).

Lindemann, J. (2010) The Economy of Brands, Basingstoke: Palgrave Macmillian.

Marzec, S. (2014) 'Strong Brand', Ethisphere, 25 February, [Online]. Available at: http://ethisphere.com/magazinearticles/strong-ethics-strong-brand-2/ (Accessed: 3 May 2014).

Maslow, A. H. (1943) 'A Theory of Human Motivation', Psychological Review, 50(4) July, pp. 370 - 396.

Meister, J. (2012) 'Corporate Social Responsibility: A Lever For Employee Attraction e Engagement', Forbes, 6 July [Online]. Available at: http://www.forbes.com/sites/jeannemeister/2012/06/07/corporate-social-responsibility-alever-for-employee-attraction-engagement/ (Accessed: 3 May 2014).

Moore, J. (2006) Tribal Knowledge: Lessons Learned from Working Inside Starbucks. Chicago: Dearborn Trade, A Kaplan Professional Company.

Morriss, A. (2012) 'How Starbucks Trains Customers to Behave', Harvard Business Review, 9 May [Online]. Available at: http://blogs.hbr.org/2012/05/how-starbucks-trains-customers/ (Accessed: 3 May 2014).

Moutinho, L., Davies, F. and Veloutsou, C. (2002) 'Future cast in in marketing: findings from an academic think tank', European Journal of Marketing, 36 (4), pp. 433-449.

Mullaney, T. (2014) Drip by drip, Starbucks lost what made it shine', Chicago Tribune [Online]. Available at: http://www. chicagotribune.com/chi-starbucks-experience-perspective,0,1699819.story (Accessed: 13 May 2014). 
Murphy, C. (2011) 'How Starbucks Taps 7 Tech Trends', Information Week, 12 August [Online]. Available at: http:/ / www.informationweek.com/it-leadership/how-starbucks-taps-7-tech-trends/d/d-id/1101730?page_number=1 (Accessed: 3 May 2014).

My Starbucks Idea (2014) Home Page. Available at: http://mystarbucksidea.force.com/apex/ideaHome (Accessed: 3 May 2014).

Nelson, B. (1998) 'How Starbucks Is Offering Not Just Jobs but Careers', Workforce, 1 November [Online]. Available at: http://www.workforce.com/articles/how-starbucks-is-offering-not-just-jobs-but-careers (Accessed: 3 May 2014).

Nisen, M. (2013) 'How Nike Solved Its Sweatshop Problem', Business Insider, 9 May [Online]. Available at: http:/ /www. businessinsider.com/how-nike-solved-its-sweatshop-problem-2013-5 (Accessed: 11 May 2014).

Pearson Business School (2014) Pre-test [Online]. Available at: http://wps.pearsoned.co.uk/ema_uk_cu_glasgow_man_ pro_2007/76/19561/5007854.cw/index.html (Accessed: 3 May 2014).

Podnar, K. and Golob, U. (2007) 'CSR expectations: the focus of corporate marketing', Corporate Communications: An International Journal, 12(4), pp. 326-340

Porter, M.E. and Kramer M.R. (2006) 'Strategy and Society: The Link Between Competitive Advantage and Corporate Social Responsibility', Harvard Business Review, December [Online]. Available at: http://hbr.org/2006/12/strategy-andsociety-the-link-between-competitive-advantage-and-corporate-social-responsibility/ar/1 (Accessed: 3 May 2014).

Porter M.E and Kramer, M.R. (2011) 'Creating Shared Value', Harvard Business Review, January-February, pp. 2-17.

Rafii, L. (2013) 'The Starbucks or McCafé Crowd: Who Counts More Politically?', Huffington Post, 11 December [Online]. http://www.huffingtonpost.com/ladan-rafii/the-starbucks-or-mccafe-c_b_4262104.html (Accessed: 3 May 2014).

Rigby, D.K. and Ledingham, D. (2004) 'CRM Done Right', Harvard Business Review, November [Online]. Available at: http://hbr.org/2004/11/crm-done-right/ar/1 (Accessed: 3 May 2014).

Rushe, D. (2013) 'The 10 best-paid CEOs in America', The Guardian, 22 October [Online]. Available at: http:/ /www. theguardian.com/business/2013/oct/22/best-paid-chief-executives-america (Accessed: 3 May 2014).

Rust, R.T., Moorman, C., Bhalla, G. (2010) 'Rethinking Marketing', Harvard Business Review, January [Online]. Available at: http://hbr.org/2010/01/rethinking-marketing/ar/1 (Accessed: 3 May 2014).

Sanburn, J. (2012) 'Do We Really Need 1,500 More Starbucks?', Time, 14 December [Online]. Available at: http:/ / business.time.com/2012/12/14/do-we-really-need-1500-more-starbucks/ (Accessed: 12 May 2014).

Shaughnessy, H. (2013) 'Starbucks Loses Reputation and McDonald's Gains, In Most Social Charts', Forbes, 20 February [Online]. Available at: http://www.forbes.com/sites/haydnshaughnessy/2013/02/20/starbucks-loses-reputationand-mcdonalds-gains-in-most-social-charts/ (Accessed: 12 May 2014).

Sisodia, R.S., Wolfe, D.B. and Sheth, J.N. (2007) Firms of Endearment: How World-Class Companies Profit from Passion and Purpose. Upper Saddle River, NJ: Wharton School Publishing.

Sky News (2014) 'Starbucks Sales Fall For First Time In 16 Years', Sky News, 25 April [Online]. Available at: http://news. sky.com/story/1249095/starbucks-sales-fall-for-first-time-in-16-years (Accessed: 11 May 2014).

Social Bakers (2014) TOP 100 Facebook Brands Social Media Stats. Available at: http://www.socialbakers.com/all-socialmedia-stats/facebook/ (Accessed: 3 May 2014).

Staff, S. (2014) 'Quality Control At Starbucks: A Team Of 7 Decides On 400 Million Pounds Of Coffee Year', Sprudge, 30 January [Online]. Available at: http://sprudge.com/fast-co-starbucks-cupping.html (Accessed: 13 May 2014).

Starbucks (2014) Our Company. Available at: http://www.starbucks.com/about-us/company-information (Accessed: 3 May 2014).

Starbucks (2014) Starbucks Company Profile. Available at: http://globalassets.starbucks.com/assets/e12a69d0d51e45d5 8567ea9fc433ca1f.pdf (Accessed: 3 May 2014).

Starbucks (2011) Terms of Use. Available at: http://www.starbucks.com/about-us/company-information/onlinepolicies/terms-of-use (Accessed: 3 May 2014).

Starbucks (2013) Global Responsibility Report Goals er Progress 2013. Available at: http:/ /www.starbucks.com/ responsibility/global-report (Accessed: 3 May 2014).

Starbucks Store (2014) Cups er Mugs. Available at: http://www.starbucksstore.com/drinkware/cups-andmugs,default,sc.html (Accessed: 3 May 2014). 
Starbucks Coffee (2013) Find Refreshment All Day, All Summer at Starbucks. Available at: http:/ /www.youtube.com/ watch?v=jk7Cuod3SJQ (Accessed: 3 May 2014).

The Economist (2009) 'Growth share matrix', The Economist, 11 September [Online]. Available at: http://www. economist.com/node/14299055 (Accessed: 3 May 2014).

The Guardian (2014) 'Starbucks to expand evening beer and wine service', The Guardian, 20 March [Online]. Available at: http://www.theguardian.com/business/2014/mar/20/starbucks-expand-beer-and-wine-service / (Accessed: w3 May 2014).

The Local (2012) 'HerM under fire for 'low' Cambodia wages', The Local, 24 October [Online]. Available at: http:/ / www.thelocal.se/20121024/44010 (Accessed: 3 May 2014).

Tietjen, D. (2013) 'Starbucks buys Teavana. First coffee dominance, now tea?', The Christian Science Monitor, 23 October [Online]. Available at: http://www.csmonitor.com/Business/2013/1023/Starbucks-buys-Teavana.-First-coffeedominance-now-tea (Accessed: 12 May 2014).

Todd, T. (2012) 'Ex-France Telecom CEO probed over 35 suicides', France 24, 7 June [Online]. Available at: http:/ / www.france24.com/en/20120705-former-france-telecom-ceo-investigated-over-staff-suicides-lombard/ (Accessed: 11 May 2014).

Tong, X. and Hawley, J.M. (2009), 'Measuring customer-based brand equity: empirical evidence from the sportswear market in China', Journal of Product er Brand Management, 18, pp. 46-61.

Traynor, D. (2014) 'CHURN, RETENTION, AND REENGAGING CUSTOMERS', Intercom [Online]. Available at: http:// insideintercom.io/churn-retention-and-reengaging-customers/ (Accessed: 3 May 2014).

Turner, R.W. (2011) Supply Management and procurement. Ft. Lauderdale: J. Ross Publishing Inc.

UK Tea er Infusions Association (2014) Tea Glossary and FAQ's [Online]. Available at: http://www.tea.co.uk/tea-faqs (Accessed: 13 May 2014)

Winchester, M., Romaniuk, J. and Bogomolova, S. (2008) 'Positive and negative brand beliefs and brand defection/ uptake', European Journal of Marketing, 42(5/6), pp. 553-570.

Wood, Z. (2011) 'Starbucks staff offered $£ 500$ of free shares', The Guardian, 26 January [Online]. Available at: http:// www.theguardian.com/business/2011/jan/26/starbucks-offers-shares-to-staff (Accessed: 3 May 2014).

Yahoo Finance (2014) Nike, Inc. (NKE) [Online]. Available at: https:/ finance.yahoo.com/echarts?s=NKE+Interactive\#s ymbol=nke;range=19901203,19981211; compare=;indicator=volume;charttype=area;crosshair=on;ohlcvalues=0;logscal e= off;source=; (Accessed: 11 May 2014).

Zapolski, J. (2010) Strategic Innovations in Product er Service Design [Online]. Available at: http:/ /sva.isotope221.com/ starbucks-primo.html (Accessed: 12 May 2014). 


\begin{tabular}{|c|c|}
\hline STRENGTHS & WEAKNESSES \\
\hline $\begin{array}{l}\text { - Top } 100 \text { Employer (Great place to work, } \\
\text { - Ethical company } \\
\text { - High quality coffee } \\
\text { - Friendly and warm interior atmosphere } \\
\text { - Stores situated in great locations } \\
\text { - A product with constant or growing } \\
\text { - } \text { demand } \\
\text { Popular place for students to study, free } \\
\text { Wi-Fi in shops }\end{array}$ & $\begin{array}{l}\text { - Expensive products for many customers } \\
\text { - Negative publicity (tax evasion) } \\
\text { - Long waiting lines in stores }\end{array}$ \\
\hline OPPORTUNITIES & THREATS \\
\hline $\begin{array}{l}\text { - Possibility to expand to more countries } \\
\text { - Open specialised stores } \\
\text { - Sell coffee or tea to large chain stores } \\
\text { - Develop a larger tea market } \\
\text { - Create official coffee farms } \\
\text { - Enhance the customer in-store experience } \\
\text { - Develop Starbucks capsules for home } \\
\text { coffee machines }\end{array}$ & $\begin{array}{l}\text { - } \text { - Lack of ownership of coffee farms } \\
\text { - Decrease in consumer bying power } \\
\text { - Rising prices of coffee and milk } \\
\text { - Saturated market } \\
\text { - Rise in sales of coffee machines for home } \\
\text { use (Espresso, Nescafe...) }\end{array}$ \\
\hline
\end{tabular}

